\title{
The influence of phenology on double-brooding and polygyny incidence in the Sedge Warbler Acrocephalus schoenobaenus
}

\author{
Tadeusz Zając $\cdot$ Wojciech Bielański \\ Adam Ćmiel · Wojciech Solarz
}

Received: 31 July 2014/Revised: 5 January 2015 / Accepted: 23 February 2015/Published online: 13 March 2015

(C) The Author(s) 2015. This article is published with open access at Springerlink.com

\begin{abstract}
There is growing evidence that the fitness of birds in temperate zones depends strongly on the match between the timing of breeding and local phenology. We have analysed data collected from a 15-year study on a Sedge Warbler (Acrocephalus schoenobaenus) population in its natural habitat. The highly skewed distribution of arrival dates of males indicated that they competed intensely to be the earliest arrivals. The distribution of mating dates, unlike arrival dates, was not skewed, rather it formed a bell-shaped distribution. Because females arrived much later, they could not base their mating choices on the arrival dates of males. Females, however, could use male song repertoire, a trait we found to be correlated with male arrival date. Double-brooded females mated early in the season, exactly within the peak of mating date distribution. Polygynous females, on the other hand, mated later in the season, choosing high-quality older males which had arrived significantly earlier. Male territory quality did not differ between double-brooded and polygynous females, nor did the quality of the territories occupied by an individual female change during her lifetime. Although longer lifespan and double-brooding influenced a female's fitness over the course of her lifetime, polygyny had no significant effect. We conclude that Sedge Warbler females do not compete for territorial resources, but they do prefer to mate with high-quality early-arriving males. Polygyny is an effective strategy used by females to compensate for their
\end{abstract}

Communicated by F. Bairlein.

T. Zając $(\bowtie) \cdot$ W. Bielański · A. Ćmiel · W. Solarz

Institute of Nature Conservation, Polish Academy of Sciences, al. Mickiewicza 33, 31-120 Kraków, Poland

e-mail: tzajac@iop.krakow.pl late arrival and breeding onset, since they pair with highquality males.

Keywords Polygyny - Second clutch - Timing of breeding $\cdot$ Mate choice $\cdot$ Territory quality $\cdot$ Arrival date

\section{Zusammenfassung}

Der Einfluss der Phänologie auf das Auftreten von Zweitbruten und Polygynie beim Schilfrohrsänger Acrocephalus schoenobaenus

Es gibt zunehmend Hinweise darauf, dass die Fitness von Vögeln in gemäßigten Breiten stark davon abhängt, wie der Brutzeitpunkt zur lokalen Phänologie passt. Wir analysierten Daten aus einer 15-jährigen Studie an einer Schilfrohrsängerpopulation im natürlichen Lebensraum. Die hochgradig schiefe Verteilung der Ankunftsdaten der Männchen wies auf eine intensive Konkurrenz um das früheste Eintreffen hin. Anders als bei den Ankunftsdaten war die Verteilung der Verpaarungsdaten nicht schief, sondern entsprach eher einer Glockenkurve. Da die Weibchen viel später eintrafen, konnten sie sich bei der Partnerwahl nicht nach den Ankunftsdaten der Männchen richten. Die Weibchen konnten sich jedoch am Gesangsrepertoire der Männchen orientieren, welches, wie wir feststellten, mit den Ankunftsdaten der Männchen korrelierte. Zweimal brütende Weibchen verpaarten sich zu Beginn der Brutsaison, genau am Verteilungsmaximum der Verpaarungsdaten. Dahingegen verpaarten sich polygyne Weibchen später in der Brutsaison und wählten hochwertigere ältere Männchen, die signifikant früher eingetroffen waren. Es gab keine Qualitätsunterschiede bei den Revieren der Männchen zwischen polygynen Weibchen und solche mit Zweitbruten; auch änderte sich die Qualität der 
Reviere, die ein Weibchen bewohnte, im Laufe seines Lebens nicht. Obwohl eine längere Lebensspanne und Zweitbruten die Fitness eines Weibchens im Laufe seines Lebens beeinflussten, hatte Polygynie keinen signifikanten Effekt. Wir folgern daraus, dass, zumindest beim Schilfrohrsänger, die Weibchen nicht um Reviere konkurrieren. Weibchen paaren sich bevorzugt mit hochwertigen, früh eintreffenden Männchen. Polygynie ist eine effektive Strategie, mittels derer Weibchen eine späte Ankunft und Brutbeginn kompensieren können, indem sie sich mit hochwertigen Männchen verpaaren.

\section{Introduction}

For migratory birds, the timing of male arrival at the breeding territory is a key determinant of male breeding success. The earliest males occupy the best territories (Aebischer et al. 1996; Petit and Petit 1996; Hasselquist 1998; Forstmeier 2002; Smith and Moore 2005; Zając et al. 2006; Sergio et al. 2007). They also mate more successfully (Alatalo et al. 1984; Møller 1994; Aebischer et al. 1996; Lozano et al. 1996; Hasselquist 1998; Kokko 1999; Currie et al. 2000), raise more progeny (Møller 1994; Hasselquist 1998; Currie et al. 2000; Cooper et al. 2011) whose survival prospects are better (Hochachka 1990; Hasselquist 1998; Currie et al. 2000; Smith and Moore 2005) and improve the quality of their territories thanks to advanced arrival dates in subsequent years (Bensch and Hasselquist 1991; Zając et al. 2011). In light of the overwhelming influence of time on male fitness, an intriguing question arises regarding the role of time in female reproductive decisions in seasonal environments.

During a spring migration, males are in more of a hurry than females because males, which usually outnumber the opposite sex, compete for restricted resources, including territories and mating opportunities (Kokko et al. 2006; Morbey et al. 2012). Nevertheless, early arrival can be costly due to bad weather or limited food resources at the time of arrival (Møller 1994; Nilsson 1994; Zając 1995; Kokko 1999; Brown and Brown 2000; Tryjanowski et al. 2004; Smith and Moore 2005; Cooper et al. 2011; Knudsen et al. 2011). The true onset of breeding, however, is probably initiated by females, since they make decisions on egg-laying. Breeding early enables them to raise multiple broods during a given season (Verboven and Verhulst 1996), which gives them an extra fitness advantage. A female that breeds early can also improve her fitness due to the higher level of recruitment of young raised in early broods (Hochachka 1990). The classic polygyny threshold model of female settlement (Verner 1964; Verner and Willson 1966; Orians 1969) predicts that early females choose the best territories and the best males. Good territories are no longer available for late-arriving females, but they can still mate with early-arriving high-quality males (Huk and Winkel 2006). However, the decision to mate as a second polygynous female may result in some disadvantages in terms of fitness (Searcy and Yasukawa 1989; Bensch 1997).

The aim of our study was to determine how reproductive decisions of the female of the Sedge Warbler Acrocephalus schoenobaenus are governed by the timing of breeding. The Sedge Warbler is a small migrant passerine which inhabits wetlands. The early-arriving males of this species pre-empt the best territories, which are characterised by proportionally large areas covered with tall wetland vegetation (Zajac et al. 2006, 2008a). The bird's polygynous behaviour, which occurs at variable frequency (Zając and Solarz 2004), is based on sequential mating: male song resumption, leading to polygyny, is related to the male's arrival date, and secondary territories are inferior to primary ones, although they do not differ in quality from the territories of unmated males (Zając et al. 2008b). It would appear that mate choice is based on the male's individual quality, as reflected in his song (Catchpole 1980; Catchpole et al. 1984; Buchanan and Catchpole 1997; Buchanan et al. 1999; Marshall et al. 2003). We used large datasets to obtain a general description of male and female arrivals and to test whether time has an influence on those female reproductive tactics which significantly impact female fitness, such as polygyny and double-brooding.

\section{Methods}

Study area

The study was conducted in 1998-2012 in natural wetlands situated in the Nida River valley, southern Poland $\left(20^{\circ} 28^{\prime}-\right.$ $20^{\circ} 32^{\prime} \mathrm{E}, 50^{\circ} 33^{\prime}-50^{\circ} 35^{\prime} \mathrm{N}$ ), between two side arms of the anastomosing river which have created two large wetland areas (labelled HT and HM) inhabited by a Sedge Warbler population.

The HT plot is the larger of the two study areas ( $36.5 \mathrm{ha}$ ) and is characterised by diversified microrelief, resulting in a large, complicated network of old riverbeds and permanently inundated areas of various sizes and depths which are concentrated in the centre and dispersed at the periphery. The inundated areas are overgrown with the common reed Phragmites australis and patches of the cattail Typha latifolia of various sizes, while the rest of the plot is covered with sedges (mainly Carex elata) and meadow communities in drier areas. This vegetation pattern is determined by the relief and thus remained fairly stable throughout the 15 years of the study, although 
cattails tended to be slowly replaced by common reeds (Bielański et al. 2005). The HM plot (10.8 ha) lies approximately $0.5 \mathrm{~km}$ to the north of HT, separated from the latter by meadows and pastures. It is fairly flat, with more homogenous vegetation: there are several very large beds of common reeds, surrounded by extensive beds of sedges. There are also a few patches of cattails, sweatgrass Glyceria sp., canary grass Phalaris arundinacea and young alders Alnus glutinosa.

The land cover of the whole area was precisely mapped using GPS $(<1 \mathrm{~m}$ accuracy) and classified according to the main vegetation types. The map was then imported into ArcGIS (ESRI, Redwoods CA) so that the features of land cover could be analysed in detail.

\section{Field protocol}

Each year, all Sedge Warbler males arriving at the study plots were promptly mist-netted and ringed with a numbered aluminium ring and a unique combination of three colour plastic rings. Females arrived noticeably later (Borowiec 1999). Over the first few years of the study, we avoided catching females immediately after arrival so as not to disrupt pair-bonding; instead, they were usually caught in the middle stages of incubation. Some females, however, were by-catches in the mist-netting of late-arriving males. Starting in 2008 we regularly caught females as they arrived and observed no negative consequences of the early catching on female behaviour.

Throughout each breeding season, we carried out detailed surveys of the study plots three times per week. The positions of all colour-ringed individuals were plotted on a map together with records of their behaviours: singing, song flights, mate guarding, conflicts, nest-building, incubating, foraging and food provisioning. Altogether, 36,314 records were gathered during the study. The data collected in the field were entered and analysed in the GIS system (ArcGIS + Access software; ESRI).

All data related to time (time of arrival of males, time of mating in females) were coded for each year according to the arrival date of the earliest male. This date was coded as ' 0 ', and subsequent dates of Sedge Warbler behavioural activities were coded according to the number of days from the date 0 . For males, we used the date of the first observations on a territory, as this date reflected the male's decision to settle in a given site. For females, the mating date was used as a reference date for female phenology (Buchanan and Catchpole 1997). Another, more practical, reason for using this date for females was that secretive females were often recorded for the first time only during pair-bond formation. The date of the first observation of a female being guarded by a male was considered to be the mating date. This guarding behaviour is relatively easy to observe in this species, as it usually coincides with the cessation of male singing behaviour (Catchpole 1980; Borowiec 1999).

Nests were located mainly by observing females carrying material for nest construction. Our visits to nests were kept to a minimum to reduce the risk of provoking nest predation or desertion. The nests were carefully inspected at the expected hatching date. On the eighth day after hatching, nestlings were ringed with a numbered aluminium ring.

\section{Territory characteristics}

It was assumed that Sedge Warbler females judge the quality of both the male and his territory (Buchanan and Catchpole 1997). For this reason, we used territory characteristics determined for males during their first day following arrival. Male territory positions do not usually change within the first part of the breeding season. After the onset of incubation, however, males which have already mated often become active again, engaging in numerous territorial conflicts or in polyterritorial behaviour (Zając et al. 2008a). Inclusion of these activities in an analysis usually obscures the boundaries of the male's territory, and it then becomes difficult to determine which observations are territory related and which are induced by conflicts or polyterritorial activities.

To estimate vegetation cover on a male's territory, we demarcated circular buffers on the digital map using the GIS software, within a radius of $30 \mathrm{~m}$ of all of the male's songposts on the first day after arrival. The sampled area roughly matched the male's territory and the immediate surroundings. The area covered by the main vegetation types was then measured for each buffer and averaged for all buffers of a given male. As we found in our earlier work (Zając et al. 2006), the Sedge Warbler clearly prefers cattails and common reeds. The presence of this type of vegetation at a site is positively correlated with the fitness of its owner, measured as mating success and local recruitment of young. For the sake of simplicity, we have presented analyses only for the sum of the area covered by cattails and common reeds, referred to hereafter as "tall wetland vegetation".

\section{Song analysis}

Songs recorded in the period 2002-2008 were analysed. In the first days after arrival (subsequent to ringing), we recorded 10-15 min of the songs of males, using Denon FN-F20R and Marantz PMD660 digital recorders (Denon, Marantz, Tokyo, Japan) equipped with a Sennheiser ME 67 microphone (Sennheiser electronic $\mathrm{GmbH} \&$ Co. KG, Wedemark, Germany). The songs were later analysed using 
Avisoft-SASLab Pro, v. 4.4 (Avisoft Bioaccoustics, Glienicke, Germany). According to methods used in studies of the song of acrocephaline warblers (Catchpole 1980), song quality was analysed in terms of the number of distinctive types of syllables occurring in the male's song. However, our experience showed that the recognition of distinctive syllables by four different researchers was somewhat subjective. For this reason, and to control the influence of different seasons, we decided to use a relative measure of song quality and adopted the percentage of the repertoire of the best male during a given season as the estimated measure of song quality for a given male.

\section{Results}

Patterns of male and female settlement

The male arrival and settling pattern (Fig. 1a) was highly skewed towards the earliest dates. The dates of the first records of females during the season were, on average, 16.4 days after the arrival of the first male (Fig. 1b), whereas mating took place, on average, on the 23rd day (Fig. 1c). Comparison of the arrival dates of matched males and females revealed that females arrived at the breeding grounds, on average, $14.4 \pm 2.70$ (standard error) days after their mates (matched pairs test, $t=5.3, n=61$, $p<0.0001)$.
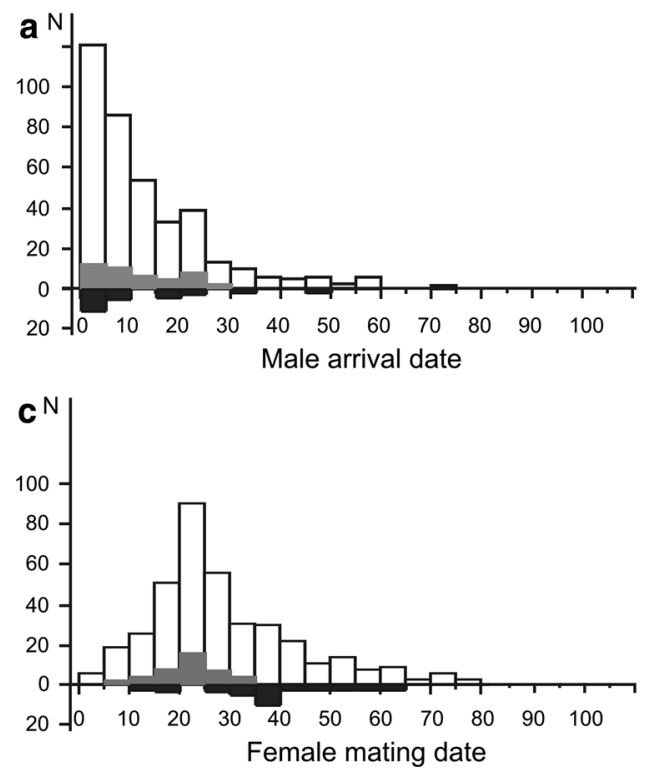

Fig. 1 Patterns of Sedge Warbler (Acrocephalus schoenobaenus) arrival at the study area. a Distribution of arrival dates of males mated to females included in analysis (white bars), including males which raised a second clutch (grey bars) and which mated polygynously (black bars with counts on reversed $Y$-axis, b distribution of female arrival dates, c distribution of female mating dates (white bars),
The distribution of female mating dates was much more symmetrical than those of the arrival dates of both males and females (Fig. 1a-c). Males which subsequently had a second clutch or which mated polygynously tended to arrive earlier (Fig. 1a; grey and black bars, respectively). In females, the pattern was different (Fig. 1c): those which laid second clutches mated precisely during the peak time of mating of all studied females. Secondary females in the polygynous system mated mainly in the later part of the mating period. The peak value of polygynous mating was found to be approximately 35-40 days after the arrival of the first male - that is, 2 weeks after the peak of monogamous mating dates (Fig. 1c; black bars). Considering the approximately 1-week interval between mating and the time of first egg-laying (Król et al. 2002), the peak dates of polygynous matings of females fell in the middle of the averaged period of incubation of the first clutch. Our data shows that there were a few unpaired males at the study sites at the time when the females mated polygynously (Fig. 1d), and this small number of unpaired males remained until the end of the breeding season.

\section{Quality of males}

The relative repertoire size and arrival dates of naive males (having no previous experience in the study area-see Zajac et al. 2006) were found to be negatively correlated (Fig. 2a). Repertoire was not significantly related to
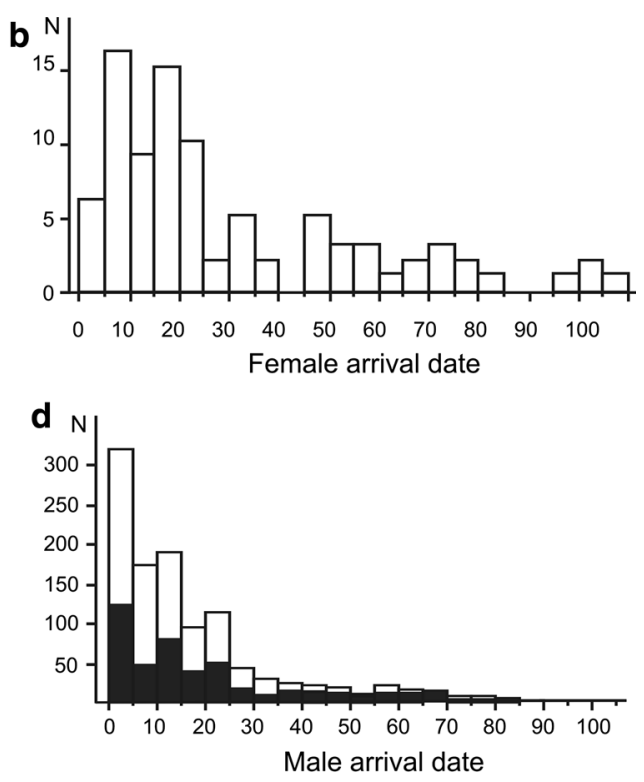

including females raising a second clutch (grey bars) and which mated polygynously (black bars), $\mathbf{d}$ distribution of the arrival dates of males which mated (white bars) and those which failed to mate (black bars). In all figures, the dates of male arrival and female mating are standardised according to the date of the arrival of the first male in a given season (equal to 0 ) 
Fig. 2 Relationship between the relative repertoire size of naive males in their first breeding season in the study site and their arrival date (a) and the quality of their territory $(\mathbf{b})$

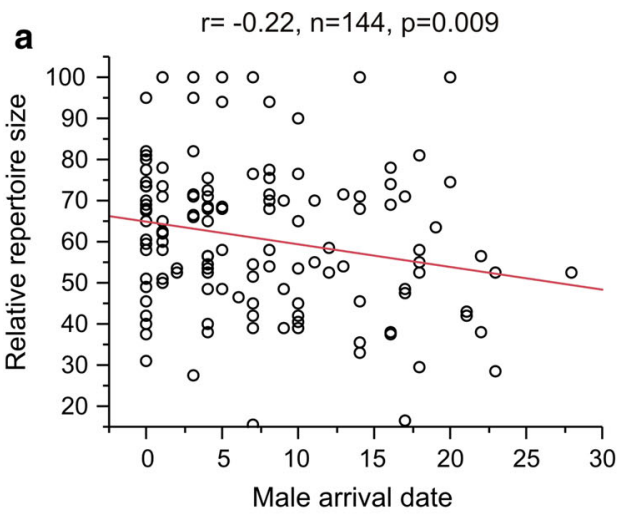

Table 1 Generalised Linear Model analysis of the relationship between male syllable repertoire and female mating date with the controlled influence of male arrival date

\begin{tabular}{|c|c|c|c|c|c|c|c|c|c|}
\hline \multirow[t]{2}{*}{ Response } & \multirow[t]{2}{*}{ Predictors: male features } & \multicolumn{4}{|c|}{ First year $(n=142)^{\mathrm{a}}$} & \multicolumn{4}{|c|}{ Second year $(n=30)^{\mathrm{a}}$} \\
\hline & & Estimate & SE & $t$ & $p$ & Estimate & SE & $t$ & $p$ \\
\hline \multirow[t]{3}{*}{ Female mating date } & Repertoire & 0.02 & 0.061 & 0.25 & 0.802 & -0.12 & 0.127 & 0.92 & 0.368 \\
\hline & Male arrival date & 0.36 & 0.117 & 3.11 & $0.002 *$ & 0.89 & 0.407 & 2.19 & 0.038 \\
\hline & Plot & -1.38 & 1.073 & 1.29 & 0.199 & 1.38 & 2.689 & 0.51 & 0.612 \\
\hline
\end{tabular}

All data were analysed with controlled influence of study plots (HM, HT; see section "Study area" for a full description of the two study sites); individuals settling outside these plots were excluded

SE Standard error

a The data were analysed separately for the first and second years of female life; the third and fourth years were excluded due to low sample sizes

territory quality (Fig. 2b). As male repertoire is known to influence the mating date (Buchanan and Catchpole 1997), we tested this relationship in Generalised Linear Model, using the female mating date as a response variable and male repertoire and male arrival date as predictors, with controlled influence of the study plot. The analysis revealed that male repertoire, when controlled for the influence of male arrival date, was not correlated with female mating date; rather, female mating date was correlated significantly only with male arrival date (Table 1).

Age of male and incidence of polygyny and doublebrooding

Of 511 cases of independently recorded male matings, 37 of which were polygynous ( 35 different males, 2 of which were polygynous twice). Polygynous matings occurred more frequently among older males (Table 2; contingency analysis, $\chi^{2}=13.5, p=0.009$ ). The same analysis performed for double-brooded males also revealed that older males were more successful in following this tactic than younger ones, although the difference only approached statistical significance (Table 2; contingency analysis, $\chi^{2}=9.37, p=0.052$ ). When this analysis was repeated for males which were both polygynous and had doublebrooded within the same season, it once again revealed the higher prevalence of this tactic in older males (Table 2; contingency analysis, $\chi^{2}=13.6, p=0.008$ ).

Time within the season and female mating tactics

For mated females, we analysed, in separate models: (1) the incidence of double-brooding (first model in Table 3) and (2) the incidence of polygynous matings (second model in Table 3) against the same set of predictors: female mating date and male arrival date. The analysis revealed that females laying second clutches mated earlier than other females (monogamous + polygynous), with no significant relation to male arrival date (Table 3; Fig. 3a). Polygynous females mated later than others (monogamous + double-brooded) but with earlier-arriving males (Table 3; Fig. 3b).

Male territory quality in relation to time within the season and female choice

The quality of territories available for settlement significantly decreased as the season progressed both in 
Table 2 The frequency of double-brooding and polygyny in females and mated males in relation to their age
Based on age at ringing and at subsequent recoveries

${ }^{a}$ Percentage of all male matings

\begin{tabular}{llcccc}
\hline Sex & $\begin{array}{l}\text { Age } \\
\text { (years) }\end{array}$ & $\begin{array}{l}\text { Total no. } \\
\text { recorded male } \\
\text { matings }\end{array}$ & $\begin{array}{l}\text { No. of double- } \\
\text { brooded males } \\
(\%)^{\mathrm{a}}\end{array}$ & $\begin{array}{l}\text { No. of polygynous } \\
\text { matings }(\%)^{\mathrm{a}}\end{array}$ & $\begin{array}{l}\text { No. of double and } \\
\text { polygynous matings }\end{array}$ \\
\hline Female & 1 & 321 & $27(8)$ & $15(5)$ & 0 \\
& 2 & 68 & $7(10)$ & $3(4)$ & 1 \\
& 3 & 17 & $2(12)$ & $3(18)$ & 2 \\
Male & 1 & 3 & $0(0)$ & $0(0)$ & 0 \\
& 2 & 91 & $80(21)$ & $19(5)$ & 6 \\
& 3 & 29 & $30(33)$ & $10(11)$ & 4 \\
& 4 & 11 & $11(38)$ & $7(24)$ & 0 \\
& 5 & 3 & $4(36)$ & $1(9)$ & 0 \\
\hline
\end{tabular}

Table 3 Generalised Linear Models testing the relationship between male arrival date and female mating date as predictors, and, as response variables, the incidence of double-brooded females among all females (model 1) and the incidence of polygynous females among all females (model 2)

\begin{tabular}{|c|c|c|c|c|c|c|c|c|c|c|}
\hline \multirow[t]{2}{*}{ Response } & \multirow[t]{2}{*}{ Model } & \multirow[t]{2}{*}{ Predictors } & \multicolumn{4}{|c|}{ Naive $(n=193)$} & \multicolumn{4}{|c|}{ Recorded second time $(n=42)$} \\
\hline & & & Estimate & SE & Wald statistic & $p$ & Estimate & SE & Wald statistic. & $p$ \\
\hline \multirow[t]{4}{*}{ Double-brooded } & 1 & Male arrival date & 0.03 & 0.025 & 1.73 & 0.188 & -0.05 & 0.046 & 1.25 & 0.264 \\
\hline & & Female mating date & -0.07 & 0.026 & 6.47 & $0.011 *$ & -0.04 & 0.070 & 0.40 & 0.528 \\
\hline & & Plot & & & 3.88 & $0.049 *$ & & & 0.21 & 0.646 \\
\hline & 2 & Male arrival date & -0.08 & 0.035 & 5.52 & $0.019 *$ & -0.01 & 0.069 & 0.04 & 0.841 \\
\hline \multirow[t]{2}{*}{ Polygyny } & & Female mating date & 0.04 & 0.016 & 7.54 & $0.006^{*}$ & 0.15 & 0.077 & 3.63 & 0.057 \\
\hline & & Plot & & & 2.58 & 0.108 & & & 0.00 & 0.997 \\
\hline
\end{tabular}

Analysed with controlled influence of the main study plots (HM, HT)

$* p \leq 0.05$

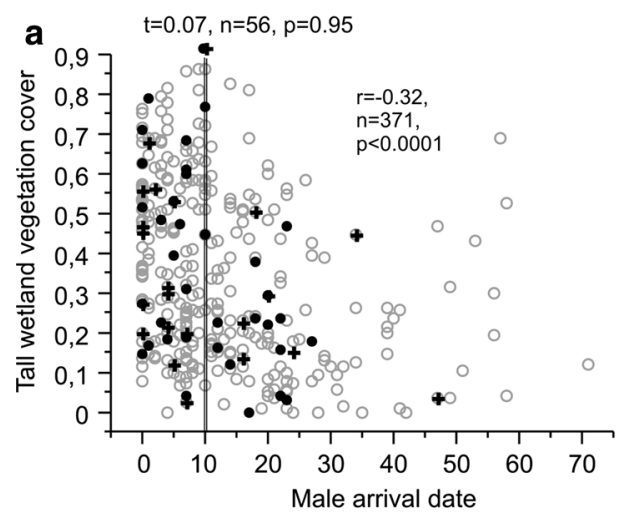

Fig. 3 The correlation $(r)$ of territory quality with male arrival date (a) and female mating date (b). Black dots data for double-brooded females, black crosses data for second polygynous females vertical lines: a mean values of arrival dates for males mated to polygynous

reference to male arrival date $(r=-0.32, n=371$, $p<0.0001$; Fig. 3a) and female-dependent mating date ( $r=-0.20, n=358, p=0.0002$; Fig. 3b). The quality of

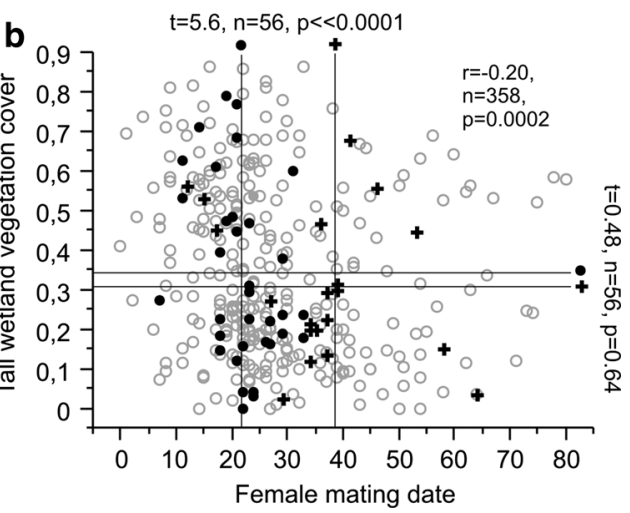

vs. double-brooded females, $\mathbf{b}$ mean mating dates for polygynous vs. double-brooded females. Horizontal lines in b Mean values of territory quality for polygynous and double-brooded females

the mates' territory did not differ significantly between double-brooded and polygynous females (horizontal lines in Fig. $3 b ; p=0.64$ ). 
Female reproductive tactics and lifetime success

The most important factor influencing a female's lifetime reproductive success in terms of local recruits was her longevity (based on age at ringing; Table 4). The incidence of double-brooding also positively influenced the number of lifetime recruits. The lifetime reproductive success of polygynous/secondary females, however, did not differ from that of females which mated monogamously.

\section{Lifetime patterns of female reproductive tactics}

Female survival between seasons was fairly low: of the 321 females ringed in HT and HM between 1998 and 2012, only $68(21 \%)$ returned to the study area in the second season of life; 17 survived until the third season, and only three survived to the fourth. Among the 47 returning females for which a full dataset was available, 46 (98\%) bred successfully in their first year of life. The ratio of successfully breeding females in their second season of life was $91 \%$; in the third, $69 \%$. Of the three females in their fourth season, two successfully raised a brood.

The frequency of double-brooded females was higher than that of polygynous females. The relative frequency of double-brooded females remained stable in each age class (based on age at ringing; Table 2; contingency analysis, $\chi^{2}=1.0, p=0.8$ ). The frequency of polygyny increased by more threefold among females in their third season of life when compared to earlier years (Table 2; difference test between two proportions: age 1 vs. $2: 5 \%$ of 321 vs. $4 \%$ of $68, p=0.73$; age 2 vs. $3: 4 \%$ (68) vs $18 \%$ (17), $p=0.040)$.

Females significantly advanced mating dates from the first to the second year of their lives (Fig. 4a). Our analysis of the distribution of these data produced interesting results (Fig. 4b): when the females that mated within the mating-

Table 4 Lifetime differences in recruit numbers between doublebrooded and polygynous females

\begin{tabular}{llllll}
\hline Response & Predictors & Estimate & SE & $\begin{array}{l}\text { Wald } \\
\text { statistic }\end{array}$ & $p$ \\
\hline $\begin{array}{c}\text { No. of recruits } \\
(n=307)\end{array}$ & Age & 0.60 & 0.12 & 23.8 & $\ll 0.0001$ \\
& $\begin{array}{c}\text { Second } \\
\text { brood } \\
\text { Polygyny }\end{array}$ & 0.53 & 0.26 & 3.97 & 0.046 \\
& 0.05 & 0.33 & 0.02 & 0.877 \\
\hline
\end{tabular}

Generalised Linear Model analysis, with the response variable being the lifetime number of recruits raised by a given female ( $0-5$; Poisson distribution, log-link function) in relation to the predictors: (1) age of a female (1-4 seasons); (2) second brood [binomial variable describing whether she laid two clutches within the same season at least once in her lifetime (1) vs. all other females (0)]; (3) polygyny, i.e. a binomial variable describing whether she was polygynous at least once during her lifetime (1) vs. all other females (0) date peak in their first season of life were compared with the same females in their second season, most of them had advanced their mating date in the second year (i.e. in Fig. 4, the greater proportion of the black bars from the first year moved towards earlier dates in the second year). There were, however, some which mated later.

Females did not change territory quality during their lives (Fig. 4c). For the same individuals there was no increase either in the number of eggs laid (although there is a visible upward trend close to statistical significance; Fig. 4d) or the number of recruits (Fig. 4e). Likewise, there were no significant differences between consecutive years of their lives in the quality of their males' songs (Fig. 4f).

\section{Discussion}

In most studies the arrival date and advantages related to early arrival from the male point of view are analysed, although some studies have studied selected features of females in this context (e.g. age; Hochachka 1990). Møller (2004) suggested that birds which arrive earlier are characterised by higher individual quality, enabling them to withstand adverse conditions during migration. Building on this suggestion, MacMynowski and Root (2007) reported that higher quality in a bird would seem to determine an earlier arrival date. In Sedge Warbler males, earlier arrival guarantees both a higher mating success and better territories (Zajac et al. 2006, 2008a). The 'race' to arrive earlier was also indicated by the highly skewed distribution of male arrival dates (Fig. 1a).

The overall picture of phenology in our data (Fig. 1) conforms to the general models (Morbey et al. 2012): male arrival date distribution indicated a very strong competition to arrive as early as possible. In females, however, the arrival date distribution is not as skewed. The symmetric, bell-shaped distribution of the peak of mating dates was highly representative due to the large sample size. This distribution suggests the existence of an optimal time for reproduction (Nilsson 1994; van Noordwijk et al. 1995).

Verboven et al. (2001) suggested that because of time constraints, double-clutch pairs of the Great Tit Parus major start their first brood sufficiently early to be able to raise two broods during the season. As a consequence, both the first and second clutch mistime food optimum, facing a trade-off: 'double clutch' vs. 'one clutch at food optimum'. In our data (Fig. 1c), the exact overlap between the distribution of the mating dates of all pairs and the doublebrooding pairs does not confirm the existence of this tradeoff. The overlap shown here may indicate that, at the beginning of their first breeding attempt, females are unable to assess their prospects to lay a second clutch; thus all of the females conform to similar laying dates. This inability 
Fig. 4 Lifetime data compared with the sign test between the consecutive seasons of female life: a mean female mating dates between seasons of life, b distribution of mating dates in females' first and second years of life (white bars) and dates of mating of the same females (black bars) shown in their first and second years of life, $\mathbf{c}$ tall wetland vegetation cover in a territory, d first clutch size, e number of local recruits, f relative repertoire size of males mated to females. $S E$ Standard error, $S D$ standard deviation
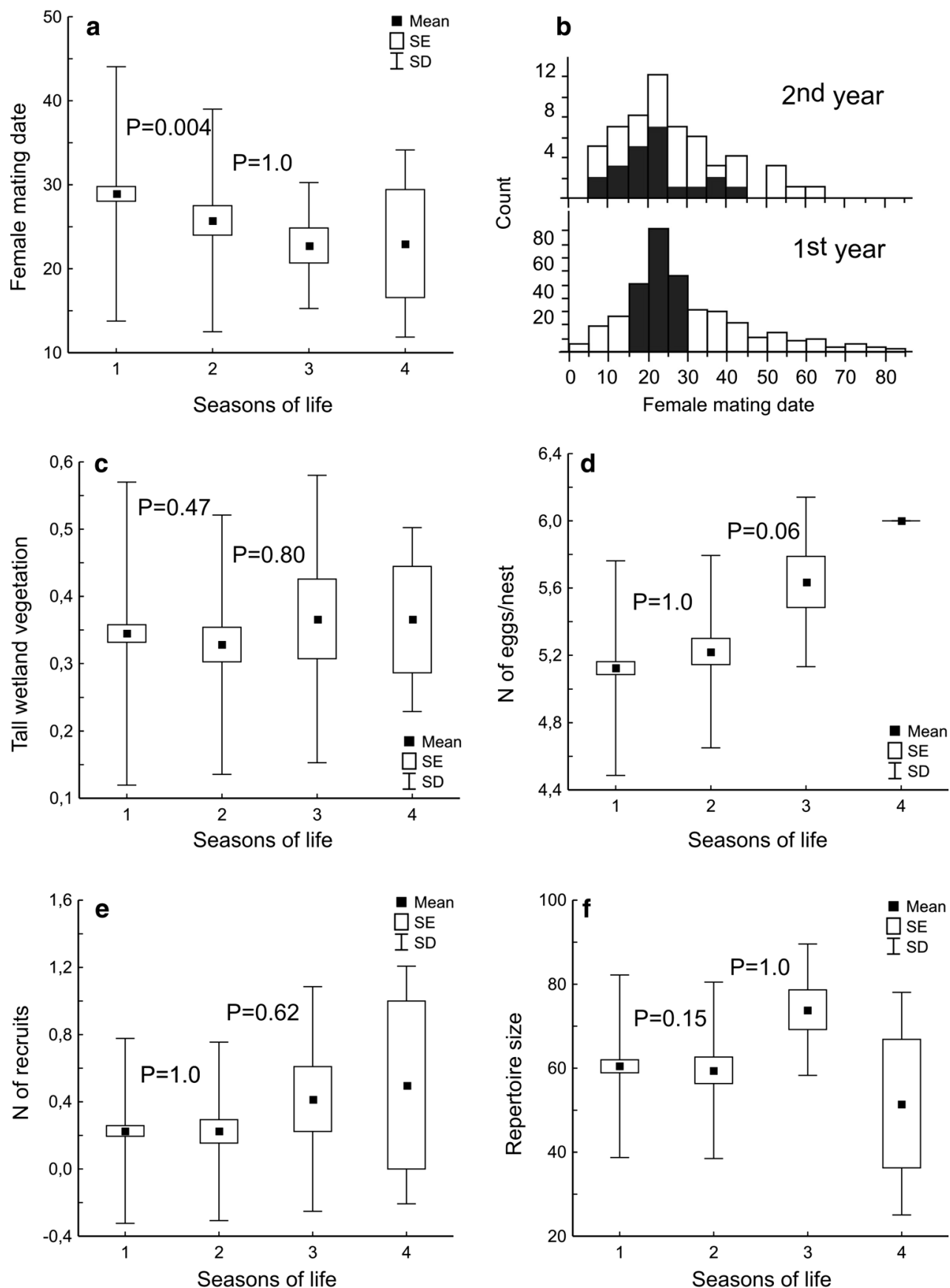

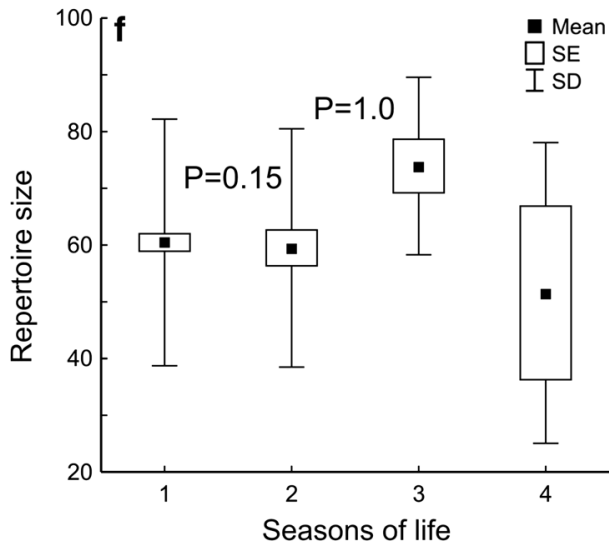

to assess future second-brood prospects seems likely since it has been frequently demonstrated that bird species miss food peaks, possibly as a result of a shift in this peak caused by global warming (Both et al. 2006; Visser et al. 2012). A number of unpredictable circumstances probably appear later in the course of the breeding season, such as the frequent occurrence of floods at the end of June (Król et al. 2002), which either enable females to lay a second clutch or prevents them from doing so.

Females usually arrive at the breeding grounds at a time when many males are already settled there; thus, females are unable to determine the males' arrival dates. However, we found a significant negative correlation between a male's song repertoire and his arrival date. This negative correlation indicates that the well-known preference of Sedge Warbler females for males with larger repertoires (Catchpole 1980) may be related to the ability of females to recognise early-arriving high-quality males (Fig. 2a).

A closer look at the influence of time on female tactics (Table 3) reveals that male arrival date is not related to double-brooding, whereas females which mated early lay two clutches. In contrast, females which mated late were 
significantly more often polygynous, although with earlyarriving males. This means that late females chose to be secondary partners of early-arriving (albeit already-mated) males of the highest quality and actually preferred this option to being the first females of inferior late males (Zajac et al. 2008b). This conforms to the results of Huk and Winkel's (2006) analysis of the long-term dataset for the European Pied Flycatcher Ficedula hypoleuca, which led the authors to conclude that the cost of polygyny might be compensated indirectly, i.e. by good genes.

In the Great Reed Warbler Acrocephalus arundinaceus, females whose mating was experimentally postponed showed a preference for early-arriving males (Bensch and Hasselquist 1992). In general, the preference of late-arriving females for early-arriving males implies that these males obtain a mating advantage, which, in turn, promotes early arrival. At the same time, late-arriving males are at a serious disadvantage because the pool of accessible females is much smaller late in the season and many late females prefer to mate polygynously. Such a mechanism promoting protandry has been described in birds [e.g. Lozano et al. (1996) for the Sedge Warbler; extra-pair fertilisations reported by Langefors et al. (1998), termed by Morbey and Ydenberg (2001) as 'mate opportunity'].

It has been demonstrated that second territories set up by Sedge Warbler males who resume singing to obtain polygynous matings are of a much lower quality than the first territories and that these second territories are similar in quality to the territories of non-breeding males (Zając et al. 2008b). This observation suggests that it is the quality of the male - and not of his territory — which governs the female's decision to mate with a male which has already mated. Polygyny in the Sedge Warbler is, as a rule, sequential, and thus asynchronous (Borowiec and Lontkowski 1988; Zając et al. 2008b), which should additionally reduce the cost of competition between females for resources in a territory (Leonard 1990), reducing in turn the importance of its quality. Unlike Hansson et al. (1997), we never observed any antagonistic behaviour of females in polygynous systems nor among females in general.

While the status of the second female can be disadvantageous (e.g. Smith and Sandell 2005; Ferretti and Winkler 2009; Grønstøl et al. 2003), such females do not lose much in terms of their fitness within the studied population. Double-brooded females have a clear advantage in terms of local recruitment over all other females, but secondary females do not differ from other females (Table 4). This indicates that polygyny is the best reproductive tactic available for late-arriving females; however, the question remains as to why some females arrive late. Figure $4 \mathrm{a}$ suggests that females advance the time of their mating over successive seasons of their life. Our comparison of mating date distributions for the same female in successive seasons
(Fig. 4b) revealed that most advanced their mating times with each successive mating season; nevertheless, some females failed to do so, or even mated later than the year before. We do not know what kind of obstacles could cause such an effect, but the most likely explanation is late arrival due to random events during migration (Newton 2007). Some of these late females might include those which had tried to breed in adjacent areas, but which had dispersed following failure (Greig-Smith 1982; Haas 1998; Grégoire and Cherry 2007; Lima 2009). If the failure occurs very early in the season (e.g. nest predation prior to completion of egg laying), then such a dispersing female might be treated as a late-arriving individual. Late arrival depletes the mating opportunities; accordingly, such females must mate quickly because there are fewer males of high individual quality available late in the season (Figs. 1d, 2a). In addition, the probability of recruitment is higher in early-mating females (Hochachka 1990; Smith and Moore 2005; Zając et al. 2006). These factors can promote polygynous matings among late females.

In conclusion, our results demonstrate that doublebrooding significantly increases the fitness of female Sedge Warblers. We failed to find negative influences of polygyny in secondary females. The choice of female tactics seems to be strongly determined by time-related factors: early females lay second broods, whereas late females mate polygynously, but only with early-arriving, high-quality males. Male song repertoire can be a direct cue enabling late females to assess male arrival date and thus individual quality.

Acknowledgements We are grateful to all those who took part in the fieldwork-in particular to Aleksandra Biedrzycka, Natalia Dzikowska, Jakub Janik, Wiesław Król, Dorota Kwaśna, Katarzyna Nowak, Bartłomiej Pirga, Małgorzata Strzałka and Katarzyna Śnigórska. The study was financed by grants from the Polish State Committee for Scientific Research Nos. 6P04F06412, 6P04F02320 and 2P04F06130, and No. N N304 328736 from the Polish Ministry of Science and Higher Education. The research reported here was conducted in full compliance with the ethical codes and legislation of the Republic of Poland.

Open Access This article is distributed under the terms of the Creative Commons Attribution License which permits any use, distribution, and reproduction in any medium, provided the original author(s) and the source are credited.

\section{References}

Aebischer A, Perrin N, Krieg M, Studer J, Meyer DR (1996) The role of territory choice, mate choice and arrival date on breeding success in the Savi's Warbler Locustella luscinioides. J Avian Biol 27:143-152

Alatalo RV, Lundberg A, Ståhlbrandt K (1984) Female mate choice in the pied flycatcher Ficedula hypoleuca. Behav Ecol Sociobiol $14: 253-261$ 
Bensch S (1997) The cost of polygyny-definitions and applications. J Avian Biol 28:345-352. doi:10.2307/3676949

Bensch S, Hasselquist D (1991) Territory infidelity in the polygynous great reed warbler Acrocephalus arundinaceus: the effect of variation in territory attractiveness. J Anim Ecol 60:857-871. doi: $10.2307 / 5418$

Bensch S, Hasselquist D (1992) Evidence for active female choice in a polygynous warbler. Anim Behav 44:301-311. doi:10.1016/ 0003-3472(92)90036-9

Bielański W, Solarz W, Zając T (2005) Patch size effect on habitat loss in Sedge Warblers Acrocephalus schoenobaenus in middle Nida Wetlands (Southern Poland). Nat Conserv 61:23-29

Borowiec M (1999) Biology and breeding ecology of a population of Sedge Warbler (Acrocephalus schoenobaenus) in the vicinity of Wrocław. Breeding behaviour and evolutionary strategies of males and females. Proc Zool Univ Wratislav 33:1-92

Borowiec M, Lontkowski J (1988) Polygyny in the Sedge Warbler Acrocephalus schoenobaenus. Vogelwelt 109:222-226

Both C, Bouwhuis S, Lessells CM, Visser ME (2006) Climate change and population declines in a long-distance migratory bird. Nature 441:81-83. doi:10.1038/nature04539

Brown CR, Brown MB (2000) Weather-mediated natural selection on arrival time in cliff swallows (Petrochelidon pyrrhonota). Behav Ecol Sociobiol 47:339-345. doi:10.1007/s002650050674

Buchanan KL, Catchpole CK (1997) Female choice in the Sedge Warbler, Acrocephalus schoenobaenus: multiple cues from song and territory quality. Proc R Soc B 264:521-526

Buchanan KL, Catchpole CK, Lewis JW, Lodge A (1999) Song as an indicator of parasitism in the Sedge Warbler. Anim Behav 57:307-314. doi:10.1006/anbe.1998.0969

Catchpole CK (1980) Sexual selection and the evolution of complex songs among European warblers of the genus Acrocephalus. Behaviour 74:149-166. doi:10.1163/156853980X00366

Catchpole CK, Dittami J, Leisler B (1984) Differential responses to male song repertoires in female songbirds implanted with oestradiol. Nature 312:563-564. doi:10.1038/312563a0

Cooper NW, Murphy MT, Redmond LJ, Dolan AC (2011) Reproductive correlates of spring arrival date in the Eastern Kingbird Tyrannus tyrannus. J Ornithol 152:143-152. doi:10.1007/s10336-010-0559-Z

Currie D, Thompson DBA, Burke T (2000) Patterns of territory settlement and consequences for breeding success in the Northern wheatear Oenanthe oenanthe. Ibis 142:389-398. doi:10.1111/j.1474-919X.2000.tb04435.x

Ferretti V, Winkler DW (2009) Polygyny in the tree swallow Tachycineta bicolor: a result of the cost of searching for an unmated male. J Avian Biol 40:289-295. doi:10.1111/j.1600048X.2008.04519.x

Forstmeier W (2002) Benefits of early arrival at breeding grounds vary between males. J Anim Ecol 71:1-9. doi:10.1046/j.00218790.2001.00569.x

Grégoire A, Cherry MI (2007) Nesting success and within-season breeding dispersal in the orange-breasted sunbird Anthobaphes violacea. Ostrich J Afr Ornithol 78:633-636

Greig-Smith PW (1982) Dispersal between nest-sites by stonechats Saxicola torquata in relation to previous breeding success. Ornis Scand 13:232-238. doi:10.2307/3676304

Grønstøl G, Byrkjedal I, Fiksen Ø (2003) Predicting polygynous settlement while incorporating varying female competitive strength. Behav Ecol 14:257-267

Grønstøl G, Hafsmo JE, Byrkjedal I, Lislevand T (2013) Chick growth and survival in northern lapwings Vanellus vanellus indicate that secondary females do the best of a bad job. J Avian Biol 44:376-382

Haas CA (1998) Effects of prior nesting success on site fidelity and breeding dispersal: an experimental approach. Auk 115:929-936
Hansson B, Bensch S, Hasselquist D (1997) Infanticide in great reed warblers: secondary females destroy eggs of primary females. Anim Behav 54:297-304

Hasselquist D (1998) Polygyny in great reed warblers: a long-term study of factors contributing to male fitness. Ecology 79:2376-2390

Hochachka W (1990) Seasonal decline in reproductive performance of Song Sparrows. Ecology 71:1279-1288

Huk T, Winkel W (2006) Polygyny and its fitness consequences for primary and secondary female pied flycatchers. Proc R Soc B Biol Sci 273:1681-1688

Knudsen E, Linden A, Both C, Jonzen N, Pulido F, Saino N, Sutherland WJ, Bach LA, Coppack T, Ergon T, Gienapp P, Gill JA, Gordo O, Hedenstroom A, Lehikoinen E, Marra PP, Moller AP, Nilsson ALK, Peron G, Ranta E, Rubolini D, Sparks TH, Spina F, Studds CE, Saether SA, Tryjanowski P, Stenseth NC (2011) Challenging claims in the study of migratory birds and climate change. Biol Rev 86:928-946

Kokko H (1999) Competition for early arrival in migratory birds. J Anim Ecol 68:940-950

Kokko H, Gunnarsson TG, Morrell LJ, Gill JA (2006) Why do female migratory birds arrive later than males? J Anim Ecol 75:1293-1303

Król W, Solarz W, Zając T (2002) Breeding biology of the Sedge Warbler Acrocephalus schoenobaenus in the river Nida wetlands (Poland). Biologia (Bratisl) 57:621-629

Langefors A, Hasselquist D, von Schantz T (1998) Extra-pair fertilizations in the Sedge Warbler. J Avian Biol 29:134-144

Leonard M (1990) Polygyny in Marsh Wrens: asynchronous settlement as an alternative to the polygyny-threshold model. Am Nat 136:446-458. doi: $10.1086 / 285106$

Lima SL (2009) Predators and the breeding bird: behavioral and reproductive flexibility under the risk of predation. Biol Rev 84:485-513

Lozano GA, Perreault S, Lemon RE (1996) Age, arrival date and reproductive success of male American redstarts Setophaga ruticilla. J Avian Biol 27:164-170

MacMynowski DP, Root TL (2007) Climate and the complexity of migratory phenology: sexes, migratory distance, and arrival distributions. Int J Biometeorol 51:361-373

Marshall RC, Buchanan KL, Catchpole CK (2003) Sexual selection and individual genetic diversity in a songbird. Proc R Soc Lond B 270:S248-S250

Møller AP (1994) Phenotype-dependent arrival time and its consequences in a migratory bird. Behav Ecol Sociobiol 35:115-122

Møller AP (2004) Protandry, sexual selection and climate change. Glob Chang Biol 10:2028-2035

Morbey YE, Ydenberg RC (2001) Protandrous arrival timing to breeding areas: a review. Ecol Lett 4:663-673

Morbey YE, Coppack T, Pulido F (2012) Adaptive hypotheses for protandry in arrival to breeding areas: a review of models and empirical tests. J Ornithol 153:207-215

Newton I (2007) Weather-related mass-mortality events in migrants. Ibis 149:453-467

Nilsson J-A (1994) Energetic bottle-necks during breeding and the reproductive cost of being too early. J Anim Ecol 63:200-208

Orians GH (1969) On the evolution of mating systems in birds and mammals. Am Nat 103:589-603

Petit LJ, Petit DR (1996) Factors governing habitat selection by prothonotary warblers: field tests of the Fretwell-Lucas models. Ecol Monogr 66:367-387

Searcy WA, Yasukawa K (1989) Alternative models of territorial polygyny in birds. Am Nat 134:323-343

Sergio F, Blas J, Forero MG, Donázar JA, Hiraldo F (2007) Sequential settlement and site dependence in a migratory raptor. Behav Ecol 18:811-821 
Smith RJ, Moore FR (2005) Arrival timing and seasonal reproductive performance in a long-distance migratory landbird. Behav Ecol Sociobiol 57:231-239

Smith HG, Sandell MI (2005) The starling mating system as an outcome of the sexual conflict. Evol Ecol 19:151-165

Tryjanowski P, Sparks TH, Ptaszyk J, Kosicki J (2004) Do White Storks Ciconia ciconia always profit from an early return to their breeding grounds? Bird Study 51:222-227

van Noordwijk AJ, McCleery RH, Perrins CM (1995) Selection for the timing of great tit breeding in relation to caterpillar growth and temperature. J Anim Ecol 64:451-458

Verboven N, Verhulst S (1996) Seasonal variation in the incidence of double broods: the date hypothesis fits better than the quality hypothesis. J Anim Ecol 65:264-273

Verboven N, Tinbergen JM, Verhulst S (2001) Food, reproductive success and multiple breeding in the Great Tit Parus major. Ardea 89:387-406

Verner J (1964) Evolution of polygamy in the long-billed marsh wren. Evolution 18:252-261

Verner J, Willson MF (1966) The influence of habitats on mating systems of North American passerine birds. Ecology 47:143-147

Visser ME, te Marvelde L, Lof ME (2012) Adaptive phenological mismatches of birds and their food in a warming world. J Ornithol 153:S75-S84
Zajac T (1995) Selection on laying date in the Blue Tit Parus caeruleus and the Great Tit Parus major caused by weather conditions. Acta Ornithol 30:145-151

Zajac T, Solarz W (2004) Low incidence of polygyny revealed in a long term study of the Sedge Warbler Acrocephalus schoenobaenus in natural wetlands of the S Poland. Acta Ornithol 39:83-86

Zając T, Solarz W, Bielański W (2006) Adaptive settlement in Sedge Warblers Acrocephalus schoenobaenus-focus on the scale of individuals. Acta Oecol 29:123-134. doi:10.1016/j.actao.2005. 07.009

Zając T, Solarz W, Bielański W (2008a) Site-dependent population dynamics: the influence of spatial habitat heterogeneity on individual fitness in the Sedge Warbler Acrocephalus schoenobaenus. J Avian Biol 39:206-214

Zając T, Bielański W, Solarz W (2008b) On the song resumption, polyterritorial behaviour and their population context in the Sedge Warbler Acrocephalus schoenobaenus. J Ornithol 149:49-57

Zając T, Bielański W, Solarz W (2011) Territory choice during the breeding tenure of male Sedge Warblers. Behav Ecol Sociobiol 65:2305-2317 